\title{
In times of COVID-19, epidemiology is a unifying science
}

Carlos Dornels Freire de Souza

1. Departamento de Medicina. Universidade Federal de Alagoas, Arapiraca, AL, Brasil.

http://dx.doi.org/10.1590/1806-9282.66.S2.27

\section{SUMMARY}

In the end of December 2019, China reported an outbreak of pneumonia in Wuhan, a city with more than 11 million inhabitants, to the World Health Organization. Days later, a new agent (SARS-CoV-2) was identified; since then, it has spread throughout the planet, resulting in one of the most challenging pandemics in recent history. Faced with this scenario, Epidemiology plays an important role, given that its techniques and methods have contributed to generating knowledge, assisting in decision making in healthcare. This text presents a succinct reflection regarding the importance of epidemiology in light of the current pandemic.

KEYWORDS: Coronavirus Infections. Epidemiology. Public Health.

\section{INTRODUCTION}

On the last day of 2019, China reported an outbreak of respiratory disease in the metropolis of Wuhan, the capital of the province of Hubei, to the World Health Organization (WHO) ${ }^{1}$. It received the name coronavirus disease 2019 (2019-nCOV); the disease is caused by the novel coronavirus SARS-CoV-2, officially identified by Chinese authorities as the cause of the disease ${ }^{1,2}$.

On January 30, 2020, the WHO declared the situation a Public Health Emergency of International Concern $^{2}$. By this date, in addition to China, 19 countries already had registered cases of the disease ${ }^{2}$. Notwithstanding the efforts undertaken, 2019-nCoV continued to spread widely, reaching new territories and causing a desolate death toll. On March 11, the WHO declared 2019-nCOV a pandemic ${ }^{3}$. Two days later, on March 13, Europe became the center of the pandemic. Within a few days, the number of deaths in Italy had already exceeded the number registered in China ${ }^{4}$. A few days later, the number of cases exploded in the United States, especially in New York City, and it rapidly reached Latin American countries such as Mexico and Brasil ${ }^{5}$.

As of May 5, 2020, the date this text was composed, 3.6 million cases had been confirmed, with 252,346 deaths. The United States (1.8 million cases), Spain (2018,011 cases) and Italy (211,938 cases) were the countries with the highest number of cases, and the United States (69,069 deaths) and Italy (29,079 deaths) had the highest number of deaths ${ }^{3}$.

Since the beginning of the outbreak in Wuhan, epidemiology has faced countless questions that needed to be answered within a short timeframe. These questions involve biological aspects [What is the origin of the virus? What are its characteristics in relation to infectivity, pathogenicity, virulence, lethality, and immunogenicity? What are its mechanisms of transmission and its potential global spread? What are the most prevalent symptoms?], quantitative sciences 
[What is the disease spread curve like? How can we predict which country will become the next epicenter of the pandemic? What is the global and local magnitude of transmission? How do incidence and mortality behave in different countries?], and even human and social sciences [What is the impact of 2019-nCoV in peripheral areas of large cities? How does the disease affect countries' social development? What measures can be taken to mitigate the harmful social effects of the pandemic? How can health systems handle the situation? What is the role of globalization in the spread of the virus and its impact on containing the epidemic?].

It is evident that these are only a few of the many questions that scientists around the world, in different areas of knowledge, are studying at this time, and it will take some years to understand the impact of the pandemic we are facing in the second decade of this century with due clarity.

Is it, then, possible to see a light at the end of the tunnel? If it exists (and we do believe that it exists), it is in epidemiology. For many years, epidemiology has produced knowledge capable of changing the course of human history ${ }^{6}$. It was during the 1854 cholera epidemic in Victorian London that John Snow challenged the scientific principles hitherto used to explain the health-disease process, which was based on miasma theory ${ }^{7}$. After using the scientific method to unveil the causal relation between cholera and the ingestion of contaminated water, science received new momentum, and Snow became the father of modern epidemiology ${ }^{7}$. Since then, it has been a fundamental instrument for understanding disease dynamics in the population. In the 1980s, epidemiology made it possible to understand the HIV epidemic ${ }^{8}$. In the second decade of the $21^{\text {st }}$ century, it was fundamental to understanding the relationship between the Zika virus epidemic and the occurrence of microcephaly in Brasil ${ }^{9}$. Epidemiology is currently facing yet another object to be understood: the 2019-nCoV pandemic.

\section{HOW CAN EPIDEMIOLOGY CONTRIBUTE TO CONTROLLING THE PANDEMIC?}

There are reasons to believe that epidemiology may contribute to controlling the 2019-nCoV pandemic. Its very concept has already provided the science with a mission: Epidemiology is the study of the health-disease process in a population and its determinants/conditions, with the goal of providing knowledge capable of changing the social-health situation ${ }^{6}$. Accordingly, epidemiological knowledge is founded upon a practical goal, namely, to contribute with solutions to populations' problems. All knowledge produced by epidemiologists should be directed toward a common good, health in its most ontological sense ${ }^{6}$.

The problem today is the 2019-nCoV. Faced with this problem, epidemiologists will need to make use of the available methodological framework (which is not little) in order to understand the dynamics of the pandemic. With advancements, epidemiology has developed different branches of study on different fronts, namely, classical, molecular, clinical, and social epidemiology, each of which has specific tools for understanding the object of study.

a) Classical epidemiology will offer knowledge regarding the magnitude of the pandemic, the main profile of patients, the risk of contracting the disease, the intensity with which the disease spreads, etc.

b) Molecular epidemiology will provide information regarding the ways the virus penetrates cells, what molecular markers increase the virulence of the agent, what mechanisms used by the host organism defend against the agent, etc.

c) Clinical epidemiology will provide information regarding the best treatment for each patient profile, what clinical conduct is most recommended for patients on mechanical ventilation in comparison with milder cases of the disease.

d) Social epidemiology will show the pandemic's impact on families, how social development may be negatively affected, or how the pandemic might increase poverty worldwide. It is evident that these deliberations are merely illustrative and that there are many others.

In addition to the specialization/division of this science, it is worth emphasizing epidemiology's ability to form bonds between the sciences. Studies carried out in different categories need to be articulated for a proper comprehension of the whole, keeping in mind that the whole is not the mere juxtaposition of the parts, but the product of the interaction between them. This is the characteristic that makes epidemiology such a relevant science.

In the pandemic we are currently experiencing, all knowledge produced in different areas must be shared because it will expand the potential comprehension of the pandemic and provide the best evidence for decision making in healthcare. Social sciences, mathematics/statistics, and biology/microbiology are the 
three main pillars that sustain the singular character of epidemiology in facing the global pandemic of 2019$\mathrm{nCoV}^{6}$. For this reason, all epidemiological knowledge is always a collective product with a common goal.

\section{WHAT IS THE NOBLE FUNCTION OF EPIDEMIOLOGY IN FACING THE PANDEMIC?}

Producing knowledge regarding a phenomenon

As more knowledge is produced, it will become less difficult to control a pandemic; fewer deaths will occur, and the global social impact of the post-pandemic economic crisis will be smaller. It is necessary to emphasize that the knowledge produced must be used for making better decisions; for this reason, it is necessary to pay attention to methodological rigor. Different study designs have specific methodological frameworks, and they should be rigorously followed. Scientific journals must adopt rigorous mechanisms in order to avoid fraud and publication of research without due ethical and scientific scrutiny. Any knowledge produced by dubious mechanisms without the necessary methodological clarity may place millions of people in jeopardy at this moment. On May 5, 2020, the term "SARS-CoV-2" yielded 3,837 publications in PubMed, and the term "COVID-19" yielded 9,225 scientific publications. The volume of publications is intense and necessary, but it requires rigorous monitoring in order to avoid a negative social impact.
To date, epidemiological investigations have shown that the containment of the pandemic must be based on measures targeting professionals, symptomatic individuals, people who have been in contact with symptomatic individuals, and the general population (Table 1). Taken together, these measures may accomplish the following ${ }^{1,10-12}$ :

1. Reduce the intensity with which the virus spreads worldwide;

2. Guarantee that healthcare systems have the capacity to attend patients, which involves human and material resources and installed capacity;

3. Reduce mortality due to the disease;

4. Reduce community transmission, flattening the 2019-nCoV spread curve over the course of weeks;

5. Provide time for scientists and health professionals to develop and/or test new therapeutic protocols.

These measures were essential for China to overcome the epidemic and halt local transmission of 2019-nCoV within its territory ${ }^{13}$. Italy neglected these measures and accumulated, as of May 5, 2020, more than 211,000 cases and more than 29,000 deaths ${ }^{14}$. The Italian healthcare system, for instance, was not able to handle the demand of diseased patients, which rapidly increased lethality ${ }^{14}$. It became necessary to decide who would receive mechanical ventilation and who would die in Italian hospitals. The lack of resources and personal protective equipment for

TABLE 1. MEASURES THAT HAVE SHOWN TO BE EFFECTIVE IN CONTAINING THE EXPANSION OF THE PANDEMIC AND AVOIDING DEATHS DUE TO 2019-NCOV.

\begin{tabular}{|c|c|c|c|c|}
\hline & $\begin{array}{l}\text { Group } 1 \\
\text { Health professionals }\end{array}$ & $\begin{array}{l}\text { Group } 2 \\
\text { Symptomatic individuals }\end{array}$ & $\begin{array}{l}\text { Group } 3 \\
\text { People who have been in } \\
\text { contact with symptomatic } \\
\text { individuals }\end{array}$ & $\begin{array}{l}\text { Group } 4 \\
\text { General population }\end{array}$ \\
\hline \multirow[t]{2}{*}{ Measures taken } & $\begin{array}{l}\text { Provide personal pro- } \\
\text { tective equipment; } \\
\text { Train health teams } \\
\text { to manage patients } \\
\text { safely. }\end{array}$ & $\begin{array}{l}\text { Offer rapid testing and } \\
\text { systematic clinical follow-up } \\
\text { of patients. }\end{array}$ & $\begin{array}{l}\text { Actively search for asymp- } \\
\text { tomatic cases and establish } \\
\text { social isolation mecha- } \\
\text { nisms. }\end{array}$ & $\begin{array}{l}\text { Institute social distancing measures; } \\
\text { Encourage attitudes of co-respon- } \\
\text { sibility from all parties during the } \\
\text { pandemic; } \\
\text { Use of masks by the general popula- } \\
\text { tion. }\end{array}$ \\
\hline & \multicolumn{4}{|c|}{ Hygiene measure - Washing hands and social etiquette } \\
\hline $\begin{array}{l}\text { Predicted } \\
\text { impact }\end{array}$ & $\begin{array}{l}\text { Reduce contamina- } \\
\text { tion in professionals } \\
\text { who are on the front } \\
\text { line; } \\
\text { Guarantee quality } \\
\text { and safety in the care } \\
\text { provided to patients. }\end{array}$ & $\begin{array}{l}\text { Stopping the chain of trans- } \\
\text { mission to other people; } \\
\text { Differential diagnosis of oth- } \\
\text { er diseases that occur with } \\
\text { similar signs/symptoms. } \\
\text { Reduce the risk of complica- } \\
\text { tions and lethality. }\end{array}$ & $\begin{array}{l}\text { Identification of asymp- } \\
\text { tomatic individuals ( } 80 \% \\
\text { of patients) and isolation } \\
\text { may slow transmission and } \\
\text { decrease the intensity of } \\
\text { the pandemic. }\end{array}$ & $\begin{array}{l}\text { Attitudes of social distancing and ed- } \\
\text { ucation may reduce disease transmis- } \\
\text { sion and avoid overloading healthcare } \\
\text { services, due to both mild cases of } \\
2019-n C o V \text { and other diseases that } \\
\text { may overload healthcare systems. }\end{array}$ \\
\hline $\begin{array}{l}\text { Overall results } \\
\text { of the measures } \\
\text { taken together }\end{array}$ & \multicolumn{4}{|c|}{$\begin{array}{l}\text { Containing the spread of } 2019-n C o V ; \\
\text { Reducing overload in healthcare systems; } \\
\text { Time for countries to prepare their healthcare networks (human and material resources); } \\
\text { Time for scientists to develop more effective therapeutic methods. }\end{array}$} \\
\hline
\end{tabular}


healthcare professionals led to the crisis worsening, and news about the death of doctors and nurses became routine in the international media ${ }^{14}$.

\section{Good use of epidemiological knowledge}

It is fundamental that the knowledge produced reaches the population given that the population is the final beneficiary of epidemiology. It must, however, be passed on to the population clearly and without distortion, in order to avoid situations of social chaos. One example is the study that indicated promising results with the use of hydroxychloroquine for treating 2019-nCoV ${ }^{15}$. In Brasil, when the president Jair Bolsonaro shared this on social media, it led to mass purchasing of the drug, leaving the population [who in fact needs this drug to continue treatment of other diseases] without access to it. It was necessary for the Brazilian National Health Surveillance Agency (ANVISA, acronym in Portuguese) to intervene in order to avoid further damage.

Furthermore, fake news and conspiracy theories must be widely combated. False claims arguing that the virus was created in Chinese laboratories or that it is only a "little cold" are merely a few examples of the situation many countries are currently facing, especially those countries that have yet to wake up to the severity of the pandemic, which is the case in
Brasil. The WHO has defended the importance of educating society regarding the severity of 2019-nCoV, as well as every citizen's role in preventing the spread of the disease ${ }^{5}$.

This text was not intended to answer questions, but rather to propose new points of reflection, therefore, it will conclude with some of the most relevant questions: It is certain that the world, science, and people will not be the same after 2019-nCoV, but what will we become? Will science and scientists be valued to the extent that they deserve, or will governments go back to forgetting about them? Will epidemiology reaffirm its social role or will it once more be pushed to the background in health systems, as is the case in many countries? Will there be a new epidemiology?

\section{Competing interests}

The authors declare that they have no competing interests

\section{Funding}

None.

\section{Author's Contribution}

CDFS reviewed and edited, were responsible for data management, analysis, and quality control. The author(s) read and approved the final manuscript.

\section{REFERENCES}

1. Zhu N, Zhang D, Wang W, Li X, Yang B, Song J, et al; China Novel Coronavirus Investigating and Research Team. A novel coronavirus from patients with pneumonia in China, 2019. N Engl J Med. 2020;382(8):727-33.

2. World Health Organization. Novel coronavirus (2019-nCoV) situation report - 11. Geneva: World Health Organization; 2020 [cited 2020 Abr 30]. Available from: https://www.who.int/docs/default-source/coronaviruse/situation-reports/20200131-sitrep-11-ncov.pdf?sfvrsn=de7c0f7_4

3. World Health Organization. Novel coronavirus (2019-nCoV) situation report - 51. Geneva: World Health Organization; 2020 [cited 2020 May 05]. Available from: https://www.who.int/docs/default-source/coronaviruse/ situation-reports/20200311-sitrep-51-COVID-19.pdf?sfvrsn=1ba62e57_10

4. Johns Hopkins University CSSE. Coronavirus COVID-19 global cases by the Center for Systems Science and Engineering (CSSE) at Johns Hopkins University CSSE. [cited 2020 May 15] Available from: https://www.arcgis.com/ apps/opsdashboard/index.htm|\#/bda7594740fd40299423467b48e9ecf6;

5. World Health Organization. Novel coronavirus (2019-nCoV) situation report - 78. Geneva: World Health Organization; 2020 [cited 2020 Abr 03]. Available from: https://www.who.int/docs/default-source/coronaviruse/ situation-reports/20200407-sitrep-78-COVID-19.pdf?sfvrsn=bc43e1b_2

6. Frérot M, Lefebvre $A$, Aho $S$, Callier $P$, Astruc $K$, Aho Glélé LS. What is epidemiology? Changing definitions of epidemiology 1978-2017. PLoS One. 2018;13(12):e0208442.

7. Fine $P$, Goldacre B, Haines A. Epidemiology: a science for the people. Lancet. 2013;381(9874):1249-52.
8. Rosenberg C. Explaining epidemics and other studies in the history of medicine. Cambridge: Cambridge University Press; 1992. p.305-17.

9. Albuquerque MFPM, Souza WV, Araújo TVB, Braga MC, Miranda Filho DB, Ximenes RAA, et al. Epidemia de microcefalia e vírus Zika: a construção do conhecimento em epidemiologia. Cad. Saúde Pública. 2018;34:e00069018.

10. Wilder-Smith A, Freedman DO. Isolation, quarantine, social distancing and community containment: pivotal role for old-style public health measures in the novel coronavirus (2019-nCoV) outbreak. | Travel Med. 2020;27(2):taaa020. doi: 10.1093/jtm/taaa020.

11. Leung NHL, Chu DKW, Shiu EYC, Chan KH, McDevitt II, Hau BIP, et al. Respiratory virus shedding in exhaled breath and efficacy of face masks. Nat Med. 2020;26(5):676-80.

12. Cowling BJ, Ali ST, Ng TWY, Tsang TK, Li JCM, Fong MW, et al. Impact assessment of non-pharmaceutical interventions against coronavirus disease 2019 and influenza in Hong Kong: an observational study. Lancet Public Health. 2020;5(5):e279-88.

13. Azman AS, Luquero FJ. From China: hope and lessons for COVID-19 control. Lancet Infect Dis. 2020;S1473-3099(20)30264-4.

14. Remuzzi A, Remuzzi G. COVID-19 and Italy: what next? Lancet. 2020;395(10231):1225-8.

15. Gautret $P$, Lagier IC, Parola P, Hoang VT, Meddeb L, Mailhe M, et al. Hydroxychloroquine and azithromycin as a treatment of COVID-19: results of an open-label non-randomized clinical trial. Int | Antimicrob Agents. 2020;105949. 